\title{
Effect of Herbal Plants "Thymus Vulgaries and Rosmarinus Officinale" on Growth Performance and Protection of Oreochromis Niloticus against Aeromonas hydrophila Infection.
}

\author{
D.A.Yassen ${ }^{1}$, E.A.Abd El-Gawad ${ }^{2}$ and A.A.Abbass ${ }^{2}$ \\ ${ }^{1}$ Directorate of Veterinary Medicine Qalyoubia Governorate, Egypt \\ ${ }^{2}$ Aquatic Animal Diseases and Management Dept., Faculty of Veterinary Medicine, Benha Univ., Egypt \\ Email: amanyabbass3@fvtm.bu.edu.eg
}

\begin{abstract}
The present study was carried out to investigate the effects of thyme and rosemary as feed additives on growth performance, cellular immunity, and protection of Oreochromis niloticus against Aeromonas hydrophila. Fish were divided into 3 groups and fed on three experimental diets (basal diet $0 \%, 1 \%$ thyme, and $1 \%$ rosemary). Fish received thyme and rosemary treated diets showed a significant increase $(P<0.05)$ in weight gain rate, specific growth rate, and average body weight at $2^{\text {nd }}$ and $4^{\text {th }}$ weeks. Feed conversion ratio revealed significant increase at $4^{\text {th }}$ weeks for thyme treated group compared to the control. Intestino-somatic index was significantly increased $(P<0.05)$ in thyme fed group at $6^{\text {th }}$ weeks while Hepato-somatic index exhibited significant increase $(P<0.05)$ at $2^{\text {nd }}$ weeks post feeding for rosemary treated fish. Blood parameters showed that total erythrocytes, packed cell volume, hemoglobin concentration, total leucocytes and differential leukocytic count were significantly increased in thyme treated group at $6^{\text {th }}$ weeks. Fish fed on rosemary-supplemented diet revealed significant increase in total leukocytic counts at $4^{\text {th }}$ and $6^{\text {th }}$ weeks, while differential leukocytic count had significant increase along the experimental period. Serum lysozyme activity was significantly increased in thyme fed group along the whole period and in rosemary treated group at $2^{\text {nd }}$ and $4^{\text {th }}$ weeks in relation with control. Nitric oxide was significantly lower in thyme fed group than the control group. Antioxidant enzymes Superoxide Dismutase, Catalase and Glutathione Reductase revealed significant increase $(P<0.05)$ with significant decrease of malondialdehyde in thyme treated group in relation with control. Challenge infection by A. hydrophila showed highly significance protection with survivable rate of $90 \%$ in groups fed with rosemary and thyme for 6 weeks. The results suggested that thyme and rosemary can be recommended as a supplementary for $O$. niloticus increasing the protection against $A$. hydrophila.
\end{abstract}

Keywords: Thyme, Rosemary, Growth performance, Immunity, Nile tilapia, Aeromonas hydrophila.

\section{Introduction}

In aquaculture bacterial diseases are the cause of significant economic losses in tilapia farms and the main mean for controlling of it, is antibiotics but using antibiotics as feed additive or therapeutics lead to appearance of resistant bacterial strain and accumulation of residues in fish and environment may reach to human [1]. On the other hand, vaccination has some disadvantages as difficult application, more labor required, high cost and impossible to develop pro-active prophylactic strategies in new diseases emerging from time to time [2]. Therefore, the application of herbal plant products as plant extract is more useful as they are safe and eco-friendly, directly taken by humans as food or medicine. They act as a substitution for feed, growth promoter, immune-stimulant, antimicrobial and as fertilizer in aquaculture with no adverse effect on natural ecosystem [3]. Thyme is used since ancient times, in the kitchen, cosmetics and for medicinal purposes. It includes thymol (44-60\%) an essential oil having strong antiseptic properties, rich in antioxidants, potassium, magnesium and vitamins $\mathrm{A}, \mathrm{C}$ and $\mathrm{E}$ [4]. The therapeutic properties of thyme in aquaculture includes anesthetic, antioxidant, digestion stimulant, antibacterial and immune enhancement [5;6]. The carnosic acid and rosmarinic acid are the main chemical constituents of rosemary and they have antioxidant and antimicrobial activity [7]. The use of thyme and rosemary increase the protection against Streptococcus agalactiae, S. iniae and A.hydrophila in O.niloticus [8], their use enhance the health condition of sea bass [9] and improved the growth performance, disease resistance and immunity of $O$. mossambicus [10] and O. niloticus [11]. The aim of this study was to evaluate the effect of thyme and rosemary on the growth performance, Immunohaematological parameters, antioxidant activity and the protection of Oreochromis niloticus against Aeromonas hydrophila infection.

\section{Materials and methods}

2.1 Fish

Nile tilapia, O. niloticus weighted $(18 \pm 1.5 \mathrm{~g})$ and average body length $(11 \pm 0.5 \mathrm{~cm})$ were obtained from Private fish farm at Kafr EL-Sheikh Governorate, Egypt and transported in double walled polyethylene bags to the wet lab at Faculty of Veterinary M-edicine Benha University. The health conditions of fish were examined for any disease condition (parasitic, bacterial) as described by Austin and Austin [12]. Fish was placed in well- 
prepared fiberglass $(750 \mathrm{~L})$ tanks filled with dechlorinated water. The water temperature was adjusted to $25 \pm 2^{\circ} \mathrm{C}$ and the oxygen level was maintained at optimal level using aerators. Fish was fed basal diet at a rate of $3 \%$ body weight twice daily. The uneaten food and excreta were siphoned and water exchange of about its third volume was done daily.

\subsection{Preparation of experimental diets}

Herbal plants (Thymus vulgaries) and (Rosmarinus officinales) were purchased from Elabed hypermarket (El Khateep spices department), Toukh, El-Kalubia Governorate. The dry whole plant of thyme and rosemary were grinded to fine powder by electrical blinder. The basal diet was divided into three parts, the first part was kept as control diet where the $2^{\text {nd }}$ part was incorporated with thyme $1 \%$, and remaining part was supplied with $1 \%$ rosemary. Suitable amount of water was added to them to form wet dough then pelleted, kept to dry at room temperature, then packed in clean dry plastic container and kept tightly closed at $4^{\circ} \mathrm{C}$.

\subsection{Feeding experiment}

Oreochromis niloticus were acclimated to lab conditions for two weeks. Fish then divided into three groups, one control and two treated groups in two replicates. The control group was fed on basal diet and two treated groups were fed on the basal diet incorporated with thyme and rosemary at a rate of $1 \%$ respectively. Fish was fed twice daily at a rate $3 \%$ of body weight for a period of six weeks from start of feeding.

\subsection{Determination of growth performance and somatic indices}

\subsubsection{Determination of growth parameters}

Sample of Ten fish were taken from each group in two replicates at the end of $2^{\text {nd }}, 4^{\text {th }}$ and $6^{\text {th }}$ weeks post feeding for determination the growth performance parameters. Weight Gain Rate (WGR), length Gain Rate (LGR), Feed Conversion Ratio (FCR), and Feed Efficiency Ratio (FER) were calculated according to Bo liu et al, [13]. Moreover, Specific Growth Rate (SGR) was determined as described by Laird and Needham [14]. Total body weight gain and average daily gain were also estimated according to Jauncey and Ross [15].

\subsubsection{Determination of bio-somatic indices}

At the end of $2^{\text {nd }}, 4^{\text {th }}$ and $6^{\text {th }}$ weeks from start of feeding, samples of ten fish from each group in two replicates were used. Liver, spleen, and intestine were taken after de-fatting. The Hepato-somatic (HSI) and Spleno-somatic (SSI) indices were calculated according to Yun et al, [16] while
Intestino-somatic index (ISI) was estimated according to Zhang et al, [17].

\subsection{Determination of hematological parameters}

At the end of $2^{\text {nd, }} 4^{\text {th }}$ and $6^{\text {th }}$ weeks blood samples were taken from control and treated groups. Blood was withdrawn from the caudal blood vessels in two portions; one with anticoagulant for measuring blood parameters and the second portion without anticoagulant for separation of serum by allowing the blood to clot at room temperature. Then the tubes were centrifuged at $3000 \times \mathrm{g}$ at $4^{\circ} \mathrm{C}$ for $15 \mathrm{~min}$, the serum was collected and stored at $-20^{\circ} \mathrm{C}$. Blood elements (RBCs and WBCs) were counted according to Kanaev [18] using Neubar-improved haemocytometer (Neubar, improved, Germany). Hemoglobin concentration was measured using the cyanomethoglobin method and differential leukocytes count (DLC) was carried out according to Stoskopf [19]. The Packed cell volume (PCV \%) and blood indices (MCV, MCH and $\mathrm{MCHC}$ ) were estimated after the method described by Dacie and Lewis [20].

\subsection{Determination of non-specific immune- parameters}

Pooled serums were used for estimation of lysozyme activity according to Schlitz [21] and serum nitric oxide was assessed according to Rajaraman et al, [22].

\subsection{Determination of antioxidant enzymes activity}

For determination of antioxidant enzymes activity, weighted liver tissues from thyme treated groups were homogenized using cool phosphate buffer saline (PBS) with PH (7.4), centrifuged at $4^{\circ} \mathrm{C}$ at $4000 \times \mathrm{g}$ for $15 \mathrm{~min}$ and keeping the supernatants at $-20^{\circ} \mathrm{C}$, where Superoxide Dismutase (SOD) and Catalase (CAT) were measured according to Fossati et al. [23]. Glutathione Reductase (GSH-Rx) and Malondialdehyde (MDA) were estimated according to Satoh [24] using commercial kits (Bio-diagnostic, Egypt).

\subsection{Challenge infection}

A. hydrophila pathogenic strain was obtained from fish diseases and management department Faculty of Veterinary Medicine, Benha University, the bacterium was grown overnight in tryptone soy broth at $28^{\circ} \mathrm{C}$, then centrifuged at $3000 \times \mathrm{g}$ for 10 minute at $4{ }^{\circ} \mathrm{C}$; the pelleted cells were washed twice and resuspended in sterile Physiological saline and adjusted to $1.5 \times 10^{8} \mathrm{cell} / \mathrm{ml}^{-1}$ by spectrophotometer $(620 \mathrm{~nm})$.

At the end of $2^{\text {nd }}$ and $4^{\text {th }}$ and $6^{\text {th }}$ weeks post feeding, ten fish (in two replicates) from each treated and control groups were intra-peritoneally 
(IP) injected with $0.2 \mathrm{ml}$ suspension of $A$. hydrophila in $0.9 \%$ saline $(\mathrm{W} / \mathrm{V})$. Mortalities were monitored over 2 weeks. Clinical signs and post mortem findings in dead and moribund fish were recorded.

\subsection{Statistical Analysis}

The data was analyzed by one- way analysis of Variance (ANOVA) and Duncan's multiple range tests to determine significant differences between groups using the statistical package for the social sciences (SPSS) software (Version 17.0). A value of $P<0.05$ was considered significant. Antioxidant enzymes activity was analyzed by independent-sample T. Test.

\section{Results and discussion}

3.1 Effect of dietary thyme and rosemary on growth performance of $\boldsymbol{O}$. niloticus

The current study showed significant increase in average body weight (ABW), weight gain rate (WGR), weight gain (WG), specific growth rate (SGR), length (L) and length gain rate (LGR) along the whole periods in $O$. niloticus fed on thyme, while groups fed on rosemary revealed a little positive effect on growth performance Table (1). Similar enhancement in growth parameters of Nile tilapia fed on thyme treated diet than other groups fed on rosemary supplied diet were recorded [25]. In addition, Yilmaz et al, [9] observed an increase in FCR of sea bass fed on $1 \%$ thyme than fish fed on $1 \%$ rosemary treated diet and Dorojan et al, [26] recorded an improvement in growth performance of Stellate Sturgeon fed with thyme. These results also came in accordance with Zaki et al, [27] who recorded significant increase of WGR and improving of the tissue nature in tilapia fed on thyme. In the same respect, Marzouk et al, [28] recorded significant increase of growth and hematological parameters in Nile tilapia fed on barely and onion supplemented diets. Moreover, using of HBP enhanced the weight gain and other growth performance parameters of Nile tilapia [29]. These observations may be due to stimulation of pancreatic enzymes secretion that necessary in nutrient digestion and adsorption [30] or presence of active compounds of thyme which act as antioxidants and hence decrease the action of stressors and enhance the aquatic welfare around the fish. Also other elements such as potassium, magnesium, ferrous, vitamins $\mathrm{A}, \mathrm{C}$ and $\mathrm{E}$ in thyme are essential for fish growth [4].

\subsection{Effect of dietary thyme and rosemary on bio- somatic indices of $\boldsymbol{O}$. niloticus}

The bio-somatic indices are considered as environmental stress indicators of fish [31]. The results in the current study revealed significant increase of intestino- somatic index in fish received thyme-supplemented diet for 6 weeks and significant increase of HSI in group fed rosemary treated diet for 2 weeks Table (2). In the same respect, significant increase of ISI in $O$. niloticus fed on 2\% ginger [32] and HBP [29] were recorded. Moreover, a little positive effect on bio-somatic indices of African catfish fed with rosemary extract was observed by Funda and Yiğitarslan [33]. The increase of intestino- somatic index may be due to an increase in thickness of intestinal tract villi [34], while the increase of HSI could be attributed to hypertrophy and hyperplasia of liver cell in fish exposed to stress [35].

\subsection{Effect of dietary thyme and rosemary on haematological parameters of $\boldsymbol{O}$. niloticus}

Haematological paramters are an important index of the health status of fish, hence infection, stress and nutrional defciency are always accompined with low level of them [36;37]. The present work showed enhancement of RBCs, PCV and $\mathrm{Hb}$ for $O$. niloticus fed on thyme and significant increases in leukocytes counts and differential leukocytic counts in both treated groups compared with control Table (3). These results were supported by Gültepe et al, [25] who recorded significance increase of haematological parameters in fish fed on $1 \%$ thyme and rosemary and by Zaki et al, [27] who showed positive effect on blood parameters in tilapia fed on $1 \%$ thyme seeds meal. In addition, Marzouk et al, [28] recorded significant increase in WBCS count in tilapia fed on herbal supplemented diet. The red blood cells indices (MCV and $\mathrm{MCH}$ ) have a wide range of physiological variation and not accurate for assessment the hematological status of fish due to manual RBC count lacks the precision necessary for the accurate assessment for calculating accurate $\mathrm{MCH}$ values [38]. Also Blaxhall and Daisley [39] recorded that $\mathrm{PCV}, \mathrm{Hb}$ and $\mathrm{MCHC}$ may be better parameters for the assessment of blood status in fish than red blood cell indices ( $\mathrm{MCV}$ and $\mathrm{MCH}$ ). Our work revealed that rosemary treated group showed slight significant increase in $\mathrm{MCH}$ at $4^{\text {th }}$ weeks compared to the control. Meanwhile, the red blood indices (MCV, MCH and MCHC) showed non-significant value in thyme treated group along the whole period Table (3). In the same manner, Ahmadifar et al, [40] and Yilmaz et al, [41] recorded non-significant values in $\mathrm{MCV}, \mathrm{MCH}$ and $\mathrm{MCHC}$ in trout fed with carvacrol treated diets compared to the control. The increases in these values may be due to macrocytic anemia, while the decreases are considered as detection of hypochromic anemia [42]. 
3.4 Effect of dietary thyme and rosemary on non-specific immunity of $\boldsymbol{O}$. niloticus

Immunological parameters (non-specific) and (adaptive-immunity) are consider the two wings of fish to resist any infection and any suppress of it led to diseases occurrence, from this parameters lysozyme activity and peroxidase activity [43]. Lysozyme is one of the most important immunity factor used by fish to resist pathogenic infection [44]. In the present study, fish fed with thyme and rosemary showed significant increase $(P<0.05)$ of lysozyme activity in first 4 weeks post feeding Table (4). Nearly similar findings were observed by Zaki et al, [27] who recorded significant increase of lysozyme activity in tilapia fed on thyme seed meal and by Giannenas et al, [45] who revealed significant increase of lysozyme activity in trout fed on carvacrol and thymol treated diets. In addition, Bilen et al, [46] reported increase of lysozyme activity of trout fed on $1 \%$ tetra (Cotinus coggyria). The increase of lysozyme activity may be due to increase of the neutrophils and lymphocytes and hence their secretion (lysozymes and hydrolytic enzymes). Nitric oxide is an intracellular mediator produced in various live cells if exposed to stress factors, while the unregulated production of nitric oxide can cause nitrosative stress, leading to damages of proteins/DNA, cell injury and death. NO concentration in serum can be used as an inflammatory marker for disease status and progression [47]. The present study showed reduction of NO production in Nile tilapia fed on $1 \%$ thyme along the whole time of experiment and at $6^{\text {th }}$ week in rosemary fed group Table (4). This result coincide with result of Giannenas et al,[45] who revealed significant decrease of NO in trout fed with thymol treated diets and Guerreiroa et al, [48] who observed lower NO level in sea bream fed with galactooligosaccharides diet. These findings could be attributed to the scavenger action of anti-oxidant compounds of thyme against any free radical and due to increase of macrophage and neutrophils cells count with humeral acidic secretions and their peroxidase pathways as inhibitory precursors that prevent synthesis of any harmful and un stable compounds in live tissues[49].

\subsection{Effect of dietary thyme on antioxidant enzymes activity of $\boldsymbol{O}$. niloticus}

In aquaculture, antioxidants play two key roles. 1 st role is, they protect the lipid in the diet from oxidative damage and the 2 nd role is protective to living tissues from destructive action of free radicles produced during metabolic process by scavenger actions [50]. Malondialdehyde is a marker of oxidative stress and considered as one of toxic byproduct of polyunsaturated fatty acid peroxidation leading to membrane and DNA damage [51]. Antioxidant enzymes including SOD, CAT and GSH-RX are representing the first line of defense against oxidative stress [52]. The present study exhibited significant increase of antioxidant enzymes, GSH-RX, SOD, CAT and significant decrease of MDA level in thyme treated groups Table (5). Several studies have been recorded decrease in MDA levels and significant increase of SOD and CAT as in rainbow trout fed on herbal treated diet [53], trout fed on thyme oils [54] and Nile tilapia fed on immunostimulant [55]. Moreover, Xie et al, [56] observed higher hepatic catalase, SOD and GSH-RX in common carp fed Chinese herbal plant. The increase in antioxidant enzymes activities could be attributed to increase the neutrophils as secretory cell of thus compounds, and ability to prevent free radical to destruct the other cells which appeared in low level of MDA. This indicated that dietary thyme activates the antioxidant enzymes, which provide tissue protection and eliminate free radicals. This was supported by the fact that when MDA appeared lower than normal level indicated good fish health condition [57].

\subsection{Challenge infection}

Herbs are rich sources of immune-enhancing substances, herbal Immunostimulant in contrast to vaccines; it can be modulating the innate or nonspecific immune response. Herbal plant extracts have anti-bacterial activity against Aeromonas hydrophila and Pseudomonas [58]. The present study revealed that $O$. niloticus fed on $1 \%$ thyme and rosemary showed reducing in mortality rates $(10 \%)$ after $6^{\text {th }}$ weeks feeding compared with $(90 \%)$ mortality for controls Fig (1). These observation supported by result of Gültepe et al,[25] and Ergün et al, [10] on O. mossambicus fed on thyme and rosemary incorporated diets which exhibited reduction in cumulative mortality in treated groups. Rosemary also increases resistance against Streptococcus agalactiae, S. iniae and Aeromonas hydrophila in Oreochromis sp. [8] and O. niloticus [59]. Similarly high level of protection against $A$. hydrophila was reported in Nile tilapia fed HBP [29] and fructooligosaccharides [60]. In the same respect an increase of the resistance against Vibrio alginolyticus infection was observed in Nile tilapia fed on Curcumin [61] and Vibrio harveyi in Asian sea bass fed on ginger containing diet [62]. They attributed this improvement in protection and reduction in mortalities to enhancement in cellular, humeral immune parameters and increases of antioxidant enzymes activities [63, 64, 65].

\section{Conclusion}

Dietary supplementation of thyme and rosemary enhance the cellular immunity and beneficial for controlling A. hydrophila infection in O. niloticus. 
Thyme improves growth performance of fish, while

fish. rosemary has a little effect on growth of Tilapia

Fig (1) Mortality \% of $O$. niloticus treated with thyme and rosemary following infection with A. hydrophila

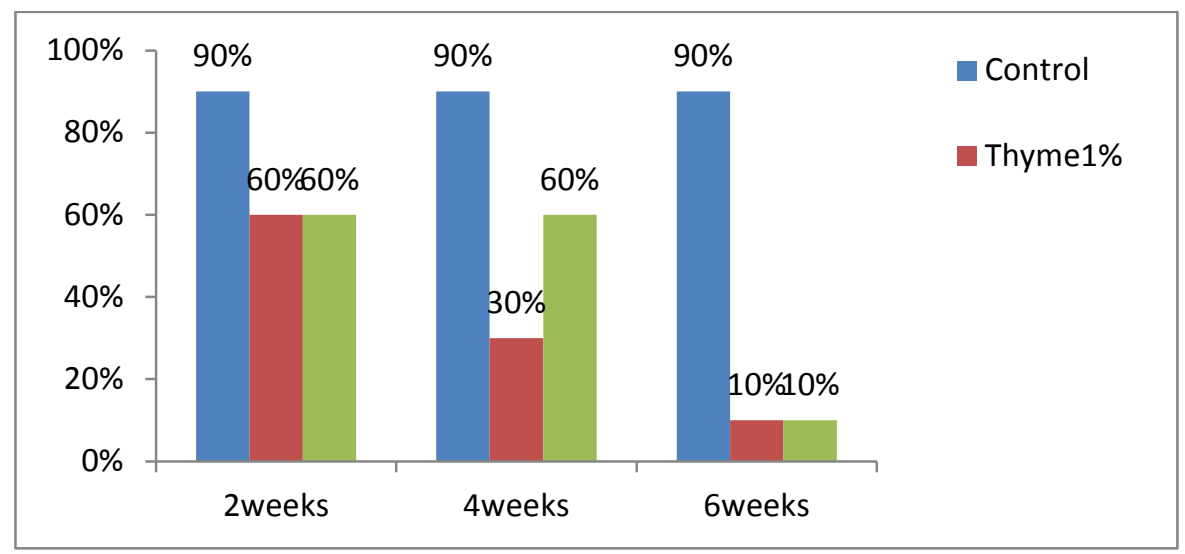

Table (1) Effect of dietary supplementation of thyme and rosemary on growth performance of $O$. niloticus.

\begin{tabular}{|c|c|c|c|c|c|c|c|c|c|c|}
\hline Groups LGR & W0 & ABW & $\mathbf{W}$ & & WG & SGR & FCR & FER & $\bar{L}$ & \\
\hline \multicolumn{11}{|c|}{ weeks } \\
\hline Control & $18.71 \pm 0.29$ & $26.38^{b} \pm 0.12$ & $41.2^{\mathrm{b}} \pm 1.55$ & $7.67^{b} \pm 0.17$ & $2.46^{b} \pm 0.08$ & $2.705 \pm 0.11$ & $0.37 \pm 0.02$ & $11.24 \pm 0.035$ & $11.36^{\mathrm{b}} \pm 0.01$ & $1.16^{\mathrm{b}} \pm 0.45$ \\
\hline Thyme1\% & $18.74 \pm 0.12$ & $28.27^{\mathrm{a}} \pm 0.24$ & $50.95^{\mathrm{a}} \pm 2.16$ & $9.55^{\mathrm{a}} \pm 0.35$ & $2.94^{\mathrm{a}} \pm 0.1$ & $2.33 \pm 0.08$ & $0.43 \pm 0.01$ & $11.19 \pm 0.02$ & $12.04^{\mathrm{a}} \pm 0.01$ & $7.59^{\mathrm{a}} \pm 0.19$ \\
\hline Rosemary1\% & $18.77 \pm 0.20$ & $28.45^{\mathrm{a}} \pm 0.01$ & $51.63^{\mathrm{a}} \pm 1.58$ & $9.68^{\mathrm{a}} \pm 0.19$ & $2.98^{\mathrm{a}} \pm 0.08$ & $2.315 \pm 0.07$ & $0.44 \pm 0.01$ & $11.25 \pm 0.02$ & $12.09^{\mathrm{a}} \pm 0.09$ & $7.46^{\mathrm{a}} \pm 0.61$ \\
\hline \multicolumn{11}{|c|}{ 4weeks } \\
\hline Contr & $18.71 \pm 0.29$ & $34.54^{\mathfrak{c}} \pm 0.00$ & 84.6 & 15.83 & $2.19^{\mathrm{b}} \pm 0.06$ & $3.44^{\mathrm{b}} \pm .15$ & $0.29 \pm 0.01$ & $11.24 \pm 0.035$ & $12.81^{b} \pm 0.05$ & $13.98^{\mathrm{b}} \pm 0.0 .23$ \\
\hline Thyme1\% & $18.74 \pm 0.12$ & $38.77^{\mathrm{a}} \pm 0.02$ & $106.98^{\mathrm{a}} \pm 1.15$ & $20.04^{\mathrm{a}} \pm 0.1$ & $2.6^{\mathrm{a}} \pm 0.02$ & $3.04^{\mathrm{a}} \pm 0.03$ & $0.33 \pm 0.01$ & $11.19 \pm 0.02$ & $13.1^{\mathbf{a}} \pm 0.02$ & $17.46^{\mathrm{a}} \pm 0.44$ \\
\hline Rosemary1\% & $18.77 \pm 0.20$ & $36.83^{\mathbf{b}} \pm 0.06$ & $96.31^{\mathrm{b}} \pm 2.46$ & $18.06^{b} \pm 0.26$ & $2.41^{\mathrm{a}} \pm 0.05$ & $3.22^{\mathrm{ab}} \pm 0.07$ & $0.31 \pm 0.01$ & $11.25 \pm 0.02$ & $12.8^{\mathrm{b}} \pm 0.02$ & $13.92^{\mathrm{b}} \pm 0.34$ \\
\hline \multicolumn{11}{|c|}{ 6weeks } \\
\hline Control & $18.71 \pm 0.29$ & $38.42^{\mathrm{b}} \pm 0.19$ & $105.39^{b} \pm 4.23$ & $19.71^{\mathbf{b}} \pm 0.49$ & $1.71^{\mathrm{b}} \pm 0.05$ & $4.6 \pm 0.16$ & $0.22 \pm 0.01$ & $11.24 \pm 0.02$ & $13.18^{b} \pm 0.05$ & $17.31^{\mathrm{b}} \pm 0.08$ \\
\hline Thyme1\% & $18.74 \pm 0.12$ & $43.45^{\mathrm{a}} \pm 0.25$ & $131.97^{a} \pm 2.74$ & $24.72^{\mathrm{a}} \pm 0.37$ & $2.01^{\mathrm{a}} \pm 0.03$ & $4.15 \pm 0.06$ & $0.24 \pm 0.01$ & $11.19 \pm 0.02$ & $13.96^{\mathbf{a}} \pm 0.02$ & $24.71^{\mathrm{a}} \pm 0.36$ \\
\hline Rosemary1\% & $18.77 \pm 0.20$ & $38.96^{b} \pm 0.02$ & $107.64^{b} \pm 2.36$ & $20.12^{\mathrm{b}} \pm .23$ & $1.74^{\mathrm{b}} \pm 0.03$ & $4.56 \pm 0.1$ & $0.21 \pm 0.01$ & $11.25 \pm 0.02$ & $13.25^{\mathbf{b}} \pm 0.02$ & $17.78^{\mathbf{b}} \pm 0.39$ \\
\hline
\end{tabular}

Values (means \pm SEM) with different letters in the same column are significantly different $(P<0.05, \mathrm{n}=10) /$ replicate.

Table (2) Effect of dietary supplementation of thyme and rosemary on Bio-somatic indices of O. niloticus.

\begin{tabular}{|c|c|c|c|}
\hline Groups ISI & SSI & & \\
\hline \multicolumn{4}{|c|}{ 2weeks } \\
\hline Control & $2.8^{\circ} \pm 0.02$ & $0.22 \pm 0.03$ & $4.69 \pm 0.02$ \\
\hline Thyme1\% & $2.78^{\mathrm{v}}+0.05$ & $0.21 \pm 0.01$ & $4.44 \pm 0.07$ \\
\hline Rosemary $1 \%$ & $3.13^{\mathrm{a}} \pm 0.07$ & $0.21 \pm 0.01$ & $4.71 \pm 0.1$ \\
\hline \multicolumn{4}{|c|}{ 4weeks } \\
\hline Control & $2.95 \pm 0.03$ & $0.14 \pm 0.01$ & $4.38 \pm 0.24$ \\
\hline Thyme1\% & $3.12 \pm 0.19$ & $0.15 \pm 0.01$ & $4.67 \pm 0.15$ \\
\hline Rosemary $1 \%$ & $2.8 \pm 0.2$ & $0.16 \pm 0.01$ & $4.24 \pm 0.11$ \\
\hline \multicolumn{4}{|c|}{ 6weeks } \\
\hline Control & $3.28 \pm .08$ & $0.24 \pm 0.01$ & $4.3^{\circ} \pm 0.01$ \\
\hline Thyme1\% & $3.02 \pm 0.05$ & $0.25 \pm 0.02$ & $5.1^{\mathrm{a}} \pm 0.1$ \\
\hline Rosemary $1 \%$ & $3.1 \pm 0.11$ & $0.29 \pm 0.02$ & $4.1^{\mathrm{D}} \pm 0.02$ \\
\hline
\end{tabular}

Values (means \pm SEM) with different letters in the same column are significantly different $(P<0.05, \mathrm{n}=10) /$ replicate

Table (3) Effect of dietary supplementation of thyme and rosemary on hematological parameters of $O$. niloticus.

\begin{tabular}{|c|c|c|c|c|c|c|c|c|c|c|c|c|}
\hline Groups & RBCs & PCV \% & $\mathrm{Hb}$ g/dl & MCV & MCH & MCHC & TLC & Monocytes & Lymphocytes & Neutrophil & Basophil & Eosinophil \\
\hline Control & $3.37^{\mathrm{a}} \pm 0.07$ & $29.20^{\mathrm{a}} \pm 0.58$ & $8.54^{a} \pm 0.12$ & $86.66 \pm 0.54$ & $25.36 \pm 0.22$ & $\frac{2 \text { weeks }}{29.26 \pm 0.18}$ & $20.16 \pm 1.93$ & $22.60^{\circ} \pm 0.51$ & $39.20^{0^{\circ}} \pm 0.66$ & $25.60^{\circ} \pm 0.93$ & $0.60 \pm 0.24$ & $0.60 \pm 0.24$ \\
\hline Thyme1\% & $3.04^{\mathrm{b}} \pm 0.13$ & $26.20^{b} \pm 1.11$ & $7.60^{b} \pm 0.34$ & $86.63 \pm 0.63$ & $24.68 \pm 0.44$ & $29.0 \pm 0.71$ & $19.72 \pm 1.59$ & $25.80^{a} \pm 0.49$ & $44.20^{2} \pm 0.37$ & $27.00^{0 \omega} \pm 0.45$ & $0.40 \pm 0.24$ & $0.40 \pm 0.24$ \\
\hline \multirow[t]{2}{*}{ Rosemary1\% } & $2.60^{\mathrm{c}} \pm 0.05$ & $22.00^{\circ} \pm 0.316$ & $6.62^{c} \pm 0.22$ & $84.68 \pm 0.96$ & $25.09 \pm 0.54$ & $30.07 \pm 0.76$ & $19.98 \pm 1.45$ & $24.80^{3} \pm 0.37$ & $42.80^{2} \pm 0.37$ & $28.00^{2} \pm 0.32$ & $0.40 \pm 0.24$ & $0.40 \pm 0.24$ \\
\hline & & & & & & 4 weeks & & & & & & \\
\hline Control & $3.32^{\mathrm{in} \pm 0.15}$ & $28.40^{\mathrm{ab}} 1.33$ & $8.23 \pm 0.44$ & $85.52^{2 b} \pm 0.32$ & $24.75^{b} \pm 0.23$ & $28.94 \pm 0.26$ & $17.8^{b} \pm 1.86$ & $22.00^{6} \pm 0.71$ & $40.80^{b} \pm 0.66$ & $26.40^{\mathrm{b}} \pm 0.51$ & $0.60 \pm 0.24$ & $0.60 \pm 0.24$ \\
\hline Thyme1\% & $3.49^{\mathrm{a}} \pm 0.11$ & $29.00^{\mathrm{a}} \pm 0.89$ & $8.54 \pm 0.25$ & $83.23^{b} \pm 0.31$ & $24.51^{b} \pm 0.11$ & $29.46 \pm 0.13$ & $14.996^{6} \pm 0.17$ & $25.20^{a} \pm 0.37$ & $45.00^{\mathrm{a}} \pm 0.45$ & $27.80^{\mathrm{a}} \pm 0.37$ & $0.40 \pm 0.24$ & $0.40 \pm 0.24$ \\
\hline \multirow[t]{2}{*}{ Rosemary1\% } & $2.96^{6} \pm 0.13$ & $25.60^{b} \pm 0.87$ & $7.42 \pm 0.43$ & $86.68^{\mathrm{a}} \pm 1.69$ & $25.99^{9} \pm 0.27$ & $29.91 \pm 0.72$ & $21.8^{\mathrm{a}} \pm 0.85$ & $24.80^{\mathrm{a}} \pm 0.49$ & $43.80^{\mathrm{a}} \pm 0.58$ & $28.60^{\AA} \pm 0.24$ & $0.40 \pm 0.24$ & $0.40 \pm 0.24$ \\
\hline & & & & & & 6 weeks & & & & & & \\
\hline Control & $3.41^{b} \pm 0.11$ & $30.20^{\mathrm{b}} \pm 0.58$ & $8.77^{b} \pm 0.20$ & $86.66 \pm 0.54$ & $25.74 \pm 0.24$ & $29.02 \pm 0.19$ & $21.63^{b} \pm 0.44$ & $24.00^{\mathrm{b}} \pm 0.32$ & $39.00^{c} \pm 0.71$ & $23.60^{b} \pm 0.81$ & $0.60 \pm 0.24$ & $0.60 \pm 0.24$ \\
\hline Thyme1\% & $4.23^{2} \pm 0.13$ & $36.40^{\mathrm{a}} \pm 1.12$ & $10.84^{ \pm} \pm 0.38$ & $85.77 \pm 0.32$ & $25.61 \pm 0.27$ & $29.77 \pm 0.39$ & $30.55^{\star} \pm 0.58$ & $25.80^{\star} \pm 0.37$ & $42.60^{\mathrm{b}} \pm 0.51$ & $28.20^{a} \pm 0.66$ & $0.40 \pm 0.24$ & $0.40 \pm 0.24$ \\
\hline Rosemary1\% & $3.48^{\mathrm{b}} \pm 0.26$ & $31.20^{\mathrm{b}} \pm 2.03$ & $8.74^{b} \pm 0.79$ & $85.54 \pm 0.69$ & $25.01 \pm 0.38$ & $29.24 \pm 0.36$ & $31.02^{\mathrm{a}} \pm 0.85$ & $25.2^{\mathrm{u}} \pm 0.37$ & $44.60^{\mathrm{a}} \pm 0.51$ & $27.40^{\mathrm{a}} \pm 0.51$ & $0.40 \pm 0.24$ & $0.40 \pm 0.24$ \\
\hline
\end{tabular}

Values (means \pm SEM) with different letters in the same column are significantly different $(P<0.05, \mathrm{n}=5) /$ replicate. 
Table (4) Effect of dietary supplementation of thyme and rosemary on lysozyme and nitric oxide of O. niloticus.

\begin{tabular}{|c|c|c|}
\hline Groups & $\begin{array}{ll}\text { Lysozyme activity } & \text { Nitric oxide } \\
\end{array}$ & \\
\hline & 2weeks & \\
\hline Control & $157.00^{\mathrm{b}} \pm 1.00$ & $6.33^{\mathrm{a}} \pm 1.33$ \\
\hline Thyme1\% & $177.90^{\mathrm{a}} \pm 0.001$ & $2.23^{\mathbf{b}} \pm 0.00$ \\
\hline \multirow[t]{2}{*}{ Rosemary $1 \%$} & $177.9^{\mathrm{a}} \pm 0.001$ & $8.57^{\mathrm{a}} \pm 0.70$ \\
\hline & 4weeks & \\
\hline Control & $178.33^{b} \pm 0.33$ & $26.67^{\mathrm{a}} \pm 0.67$ \\
\hline Thyme1\% & $200.04^{\mathrm{a}} \pm 0.002$ & $21.90^{\mathbf{b}} \pm 0.80$ \\
\hline \multirow[t]{2}{*}{ Rosemary $1 \%$} & $200.04^{\mathrm{a}} \pm 0.001$ & $28.57^{\mathrm{a}} \pm 0.73$ \\
\hline & 6weeks & \\
\hline Control & $207.3^{\mathrm{a}} \pm 7.33$ & $41.67^{\mathrm{a}} \pm 0.33$ \\
\hline Thyme1\% & $200.04^{\mathrm{a}} \pm 0.00$ & $16.70^{c} \pm 0.00$ \\
\hline Rosemary $1 \%$ & $177.90^{\mathbf{b}} \pm 0.00$ & $28.87^{\mathbf{b}} \pm 2.07$ \\
\hline
\end{tabular}

Values (means \pm SEM) with different letters in the same column are significantly different $(P<0.05, \mathrm{n}=3) /$ replicate

Table (5) Effect of dietary supplementation of thyme on antioxidant enzymes activity of $O$.niloticus.

\begin{tabular}{|c|c|c|c|c|}
\hline Groups & SOD & CAT & GSH-Rx & MDA \\
\hline \multicolumn{5}{|c|}{ 2weeks } \\
\hline Control & $1086.10^{\mathrm{b}} \pm 0.06$ & $3.80 \pm 0.30$ & $17.57^{b} 0.27$ & $355.00 \pm 0.001$ \\
\hline Thyme1\% & $2120.35^{\mathrm{a}} \pm 0.20$ & $2.74 \pm 0.56$ & $85.43^{\mathrm{a}} \pm 0.25$ & $509.19 \pm 0.11$ \\
\hline \multicolumn{5}{|c|}{ 4weeks } \\
\hline Control & $1362.07 \pm 0.03$ & $3.13 \pm 0.23$ & $67.20^{b} \pm 0.25$ & $375.20^{\mathbf{b}} \pm 0.10$ \\
\hline Thyme1\% & $1155.06 \pm 0.06$ & $1.78 \pm 0.12$ & $109.68^{\mathrm{a}} \pm 3.11$ & $118.50^{\mathrm{a}} \pm 0.002$ \\
\hline \multicolumn{5}{|c|}{ 6weeks } \\
\hline Control & $1224.07 \pm 0.03$ & $1.47^{\mathrm{b}} \pm 0.17$ & $87.20^{\mathrm{b}} \pm 4.95$ & $493.90^{\mathrm{b}} \pm 7.81$ \\
\hline Thyme1\% & $1224.09 \pm 0.05$ & $2.13^{\mathrm{a}} \pm 0.047$ & $113.55^{\mathrm{a}} \pm 0.03$ & $458.20^{\mathrm{a}} \pm 0.11$ \\
\hline
\end{tabular}

Values (means \pm SEM) with different letters in the same column are significantly different $(P<0.05, \mathrm{n}=3) /$ replicate

\section{References}

[1] A.Syahidah, C.R.Saad, H.M. Daud, Y.M. Abdelhadi. Status and potential of herbal applications in aquaculture. Iranian Journal of Fisheries Sciences, Vol. 14(1), pp.27-44, 2015.

[2] R. Harikrishnan, C. Balasundaram. Modern trends in Aeromonas hydrophila disease management with fish. Reviews in Fisheries Science, Vol 13, pp. 281-320, 2005.

[3] K.R. Ramudu, G. Dash. A Review on Herbal Drugs against Harmfull Pathogens in Aquaculture. American Journal of Drug Discovery and Development, Vol 3, pp. 209219, 2013.

[4] Z.Alçiçek. The effects of thyme (Thymus vulgaris $L$ ) oil concentration on liquid-smoked vacuum-packed rainbow trout (Oncorhynchus mykiss Walbaum, 1792) fillets during chilled storage. Food Chemistry, Vol 128 (3), pp.683688, 2011.

[5] M.C.Rota, A. Herrera, R.M. Martinez, J.A. Sotomayor, M.J. Jordan. Antimicrobial activity and chemical composition of Thymus vulgaris, Thymus zygis and Thymus hyemalis essential oils. Food Control, Vol 19 (7), pp. 681-687, 2008.

[6] I.S.Azad, A. Al-Yaqout, M. Al-Roumi. Antibacterial and immunity enhancement properties of anaesthetic doses of thyme
(Thymus vulgaris) oil and three other anaesthetics in Sparidentax hasta and Acanthopagrus latus. Journal of King Saud University - Science, Vol 26 (2), pp. 101106, 2014.

[7] N.Erkan, G. Ayranci , E. Ayranci. Antioxidant activities of rosemary (Rosmarinus officinalis L.) extract blackseed (Nigella sativa L.) essential oil, carnosic acid, rosmarinic acid and sesamol. Food Chemistry, Vol110 (1), pp.76-82, 2008.

[8] D.Zilberg, A. Tal, N. Froyman, S. Abutbul, N. Dudai, A. Golan-Goldhirsh. Dried leaves of Rosmarinus officinalis as a treatment for streptococcosis in tilapia. Journal of Fish Diseases, Vol 33, pp. 361-36, 2010.

[9] S.Yilmaz, S. Ergün, E.S. Celik. Effects of herbal supplements on growth performance of seabass (Dicentrarchus Labrax): change in body composition and some blood parameters, Journal of Bioscience and Biotechnology, Vol 1(3), pp. 217-222, 2012.

[10] S.Ergün, S.Y1lmaz, M.Yigit. Effects of thyme, rosemary and fenugreek on some hematological and immunological parameters of tilapia, Oreochromis mossambicus. Mediterranean Aquaculture 2020, Aquaculture Europe (EAS 2011); 2011 Oct 19-21; Rhodes-Greece, pp. 18$21,2011$. 
[11] S.Abutbul, A.Golan-Goldhirsh, O. Barazani, D.Zilberg. Use of Rosmarinus officinales as a treatment against Streptococcus iniae (Oreochromis sp.). Aquaculture, Vol 238 (1-4), pp. 97-105, 2004.

[12] B.Austin, D.A.Austin. Method for microbiological examination of fish and shellfish. Chichester: Ellis Horwood; New York: Halsted Press, 1989, pp 317-327.

[13] X.Bo liu, H.Yanhui, P.Jun, Q.Xigin, C.Ruli . Effects of anthraquinones extracted from Rheum officinale Bail on the growth, non-specific immune response of Macrobrachium rosenbergii. Aquaculture, Vol 310, pp. 13-19, 2010.

[14] L.M. Laird, T.Needham. Growth, nutrition and feeding, Salmon and trout farming, England, Ellis Horwood Limited, 1988, PP 202-216.

[15] K. Jauncey, B. Ross. A guide to tilapia feeds and feeding. Institute of Aquaculture, University of Stirling Scotland, 1982, Pp. 111.

[16] B. Yun, Q. Ai, K. Mai, W. Xu, G. Qi, Y. Luo. Synergistic effects of dietary cholesterol and taurine on growth performance and cholesterol metabolism in Juvenile turbot (Seophthalmus Maximus) fed high plant protein diets. Aquaculture, Vol 324-325, pp. 85-91, 2012.

[17] Q.Zhang, J.Wu, J.S.Chen, Y.Feng. Influences of organic pollutants in water on antioxidant enzyme in zebra fish. Journal of chemical and pharmaceutical Research, Vol 6 (4), pp. 10141021. 2014.

[18] A.F.Kanaev. Veterinary Hygiene in Fish Farming. Moscow, 1985, PP 140-194.

[19] M.K.Stoskopf. Fish medicine. Sounders Company, U.S.A 1993, Pp 882.

[20] J.V.Dacie, S.M.Lewis. Practical Haematology, 7th Edition, Churchill Livingstone, Edinburgh, 1991, pp.54-79.

[21] L.A.Schlitz. Veterinary Haematology. $3^{\text {rd }}$ edition, Lea, and Febiger. Pp. 217-222, 1987.

[22] V.Rajaraman, B.J. Nonnecke, S.T. Franklin, D.C.Hammell,R.L.Horst. Effect of vitamin A and $\mathrm{E}$ on nitric oxide production by mononuclear leukocytes from neonatal calves fed milk replacer. Journal of Dairy science, Vol 81, pp. 3278-3285, 1998.

[23] P. Fossati, L.Prencipe, G.Berti. Use of 3, 5dichloro-2-hydroxybenzenesulfonic acid/4aminophenazone chromogenic system in direct enzymatic assay of uric acid in serum and urine. Clinical Chemistry, Vol 26, pp. 227-23, 1980.

[24] K. Satoh. Serum lipid peroxide in cerebrovascular disorder determined by a new colorimetric method. Clinica Chimica Acta, Vol 90, pp. 37-43, 1978.

[25] N. Gültepe, S. Bilen, S. Y1lmaz, D. Güroy, S. Aydin. Effects of herbs and spice on health status of tilapia (Oreochromis mossambicus) challenged with Streptococcus iniae. Acta Veterinaria Brno, Vol 83, pp. 125-131, 2014.

[26] O.G.Dorojan (Varlan), V. Cristea, S. Ion, Ş.M. Petrea. The Influence of some Phytobiotics (Thyme, Seabuckthorn) on Growth Performance of Stellate Sturgeon (A. stellatus, Pallas, 1771) in an Industrial Recirculating Aquaculture System. Animal Science and Biotechnologies, Vol 47 (1), pp.205-210, 2014.

[27] M.A. Zaki, E.M. Labib, A.M. Nour, H.D. Tonsy, S.H. Mahmoud. Effect of some medicinal plants diets on the mono-sex Nile Tilapia (Oreochromis niloticus), growth performance, feed utilization and some physiological paramters. APCBEE Procedia ,Vol 4, pp. 220-227, 2012.

[28] M.S.M.Marzouk, M.A.Abdel Aziz, W.S. Soliman, H.H.Abbas, S.Z.Mona, E. Awad, B.A. Sahr. Effect of some herbal extracts on the health status of cultured Oreochromis niloticus. Research Journal of Pharmaceutical, Biological and Chemical Sciences, Vol 8(1), pp. 14571466, 2017.

[29] A.M.ELAsely, A.A.Abbass, B.Austin. Honey bee pollen improves growth, immunity and protection of Nile tilapia (Oreochromis niloticus) against infection with Aeromonas hydrophila. Fish and Shellfish Immunology, Vol 40, pp.500-506, 2014.

[30] T. Frankic, M.Voljc, J.Salobir, V.Rezar. Use of herbs and spices, and their extracts in animal nutrition. Acta Argiculturae Slovenica, Vol 94 (2), pp.95-102, 2009.

[31] B.A.Barton, J.D.Morgan, M.M.Vijayan. Physiological and condition-related indicators of environmental stress in fish. Chapter 4 in S.M. Adams, editor. Biological indicators of aquatic ecosystem stress. American Fisheries Society, Bethesda, Maryland, 2002, Pp: 111148.

[32] M.N. Islam. Effect of some immunostimulants on growth performance and immune status of Nile tilapia (Oreochromis niloticus). M.V.SC. Thesis (Fish Diseases and Management), Faculty of Veterinary Medicine, Benha University, 2015.

[33] T. Funda, D. Yiğitarslan. The Effects of Rosemary Extract (Rosmarinus officinalis) as a Feed Additive on Growth and Whole-body Composition of the African Catfish (Clarias gariepinus (Burchell, 1822)). Natural and Engineering Sciences, vol 1 (3), pp.49-55, 2016.

[34] J. Wang, S. Li, Q. Wang, B. Xin, H. Wang. Trophic effect of bee pollen on small intestine in broiler chickens. Journal of Medicinal Food, vol 10, pp. 276-80, 2007.

[35] S.O. Ayoola. Histopathological effects of glyphosate on juvenile African catfish (Clarias gariepinus). American-Eurasian Journal of 
Agriculture and Environmental Sciences, vol 4, pp. 362-367, 2008.

[36] J. Rehulka. Influence of astaxanthin on growth rate, condition factor and some blood indices of rainbow trout, Oncorhynchus mykiss. Aquaculture, vol 90, pp. 27-47, 2000.

[37] J. Rehulka. Aeromonas causes severe skin lesions in rainbow trout (Oncorhynchus mykiss): clinical pathology, haematology, and biochemistry. Acta Veterinaria Brno, vol 71, pp.351-60, 2002.

[38] J.E. Arnold. Hematology of the sandbar shark, Carcharinus plumbeus: standardization of complete blood count techniques for elasmobranches. Journal of Veterinary Clinical Pathology, vol 34 (2), pp. 115-123, 2005.

[39] P.C. Blaxhall, , K.W. Daisley. Routine haematological methods for use with fish blood. Fish Biology, vol 5, pp. 771-781, 1973.

[40] E. Ahmadifar, B. Falahatkar, R. Akrami. Effects of Dietary Thymol-Carvacrol on Growth Performance, Hematological Parameters and Tissue Composition of Juvenile Rainbow Trout, (Oncorhynchus mykiss). Journal of Applied Ichthyology, vol 27 (4), pp.1057-1060, 2011.

[41] E. Yilmaz, S. Ergün, S. Yilmaz. Influence of carvacrol on the Growth performance, Hematological, Non-Specific Immune and Serum Biochemistry Parameters in Rainbow Trout (Oncorhynchus mykiss). Food and Nutrition Sciences, Vol 6, pp. 523-531, 2015.

[42] C.Mirea (Ciortan), V. Cristea, R.I. Grecu, L. Dediu, V.Ion. Hematological and Biochemical Characterization of Nile tilapia (Oreochromis niloticus, Linnaeus, 1758) Reared Intensively in a Recirculating Aquaculture System in Relation to Water Temperature. Animal Science and Biotechnologies, Vol 46 (2), pp. 234-237, 2013.

[43] B. Magnadottir. Immunological control of fish diseases. Journal of Marine Biotechnology, Vol 12, pp. 361-379, 2010.

[44] G.Feng, X.Shi, X.Huang, P.Zhuang. Oxidative stress and antioxidant defenses after long-term fasting in blood of Chinese sturgeon (Acipenser sinensis). Procedia Environmental Sciences, Vol 8, pp.469-475, 2011.

[45] 1.Giannenas, E.1.Triantafillou, S. Stavrakakis, M.Margaroni, S.Mavridis, T.Steiner, E.Karagouni. Assessment of dietary supplementation with carvacrol or thymol containing feed additives on performance, intestinal microbiota and antioxidant status of rainbow trout (Oncorhynchus mykiss). Aquaculture, Vol 350-353, pp. 26-32. 2012.

[46] S.Bilen, M.Bulut, , A.M.Bilen. Immunostimulant effects of Cotinus coggyria on rainbow trout (Oncorhynchus mykiss). Fish and shellfish immunology, Vol 30, pp. 451-455, 2011.
[47] M.P.Murphy. Nitric oxide and cell death. Biochimica et Biophysica Acta, Vol 1411 (2-3), pp. 401-414, 1999.

[48] N. Guerreiroa, M. Machadoa, C. Castroa, B. Costasa, A.O.Aires Telesa, P.Enesa. Prebiotics effect on immune and hepatic oxidative status and gut morphology of white seabream (Diplodus sargus). Fish and Shellfish Immunology, Vol 50, pp. 168-174, 2016.

[49] A. Cuesta, A. Rodríguez, M.A. Esteban, J. Mrseguer. In vivo effect of propolis, a honeybee product, on gilt head seabream innate immune responses. Fish and shellfish Immunology, Vol 18 , pp. 71-80, 2005.

[50] H.Hashemipour, H.Kermanshahi, A. Golian, T.Veldkamp. Effect of thymol and carvacrol feed supplementation on performance, antioxidant enzyme activities, fatty acid composition, digestive enzyme activities and immune response in broiler chickens. Poultry Science, Vol 92, pp. 2059-2069, 2013.

[51] D. Livingstone. Oxidative stress in aquatic organisms in relation to pollution and aquaculture. Revue de Médecine Vétérinaire, vol 154, pp. 427-430, 2003.

[52] V.I.Lushchak. Environmentally induced oxidative stress in aquatic animals. Aquatic Toxicology, Vol 101, pp.13-30, 2011.

[53] L.Chan, X.U. Qi-You, X.U. Hong, Z. Tie-qi. Effects of different feed additives on immunity and antioxidation on rainbow trout (Oncrhynchus mykiss Walbaum). Journal of Anhui Agricultural University, Vol 35, pp. 456461, 2008.

[54] A.Y. Sönmez, S. Bilen, , G.Alak, O. Hisar, T. Yanık, G. Biswas. Growth performance and antioxidant enzyme activities in rainbow trout (Oncorhynchus mykiss) juveniles fed diets supplemented with sage, mint and thyme oils. Fish Physiology Biochemistry, Vol 41(1), pp. 165-75, 2015.

[55] E.A.Abdel Gawad,A.M. Abdel EL-lattif, R.M. Shourbela. Enhancement of antioxidant activity, Non-specific Immunity and growth performance of Nile tilapia (Oreochromis niloticus) by dietary fructooligosaccharides. Journal of Aquaculture research \& development, Vol 7 (5), pp. 427-433, 2016.

[56] J.Xie, B. Liu, Q. Zhou, Y. Su, Y. He, L. Pan, X. Ge, P. Xu. Effects of anthraquinones extract from rhubarb Rheum officinale Bail on the crowding stress response and growth of common carp Cyprinus carpio var. Jian. Aquaculture, Vol 281(1-4), pp. 5-11, 2008.

[57] A. Yildirim, A. Mavi, M. Oktay, A.A. Kara, O.F. Algur, V. Bilaloglu. Comparison of antioxidant and antimicrobial activities of tilia (Tilia argentea Desf ex DC), sage (Salvia triloba 1.), and black tea (Camellia sinensis) 
extracts. Journal of Agriculture and Food Chemistry, Vol 48(10), pp. 5030-5034. 2001.

[58] E.H.Hardi, I.W.Kusuma, W.Suwinarti, Agustina, R.A. Nugroho. Antibacterial activity of Boesenbergia pandurata, Zingiber zerumbet, and Solanum ferox extracts against Aeromonas hydrophila and Pseudomonas sp. Nusantara Bioscience, Vol 8, pp.18-21, 2016.

[59] A.M.M. Abdel-Zaher, M.H.Ahmad, A. Mousallamy, A. Samir. Effect of using dried fenugreek seeds as natural feed additives on growth performance, feed utilization, whole body composition and entropathogenic Aeromonas hydrophila challinge of monsex Nile Tilapia $O$. Niloticus (L) fingerlings. Australian Journal of Basic and Applied Sciences, Vol 3 (2), pp. 1234-1245, 2009.

[60] E.A. Abdel Gawad, A.M. Abdel EL-lattif, A. A. Amin, M.A. Abdel-EL-Azem. Effect of dietary fructooligosaccharides on bacterial infection, oxidative stress and histopathological alteration in Nile tilapia (Oreochromis niloticus). Journal of Global veterinary, Vol 15 (4), pp.339-350, 2015.

[61] M.Y. Elgendy, A.S. Hakim, T.B. Ibrahim, W.S. Soliman, S.E. Ali. Immunomodulatory Effects of Curcumin on Nile Tilapia and its Antimicrobial Properties against Vibrio alginolyticus. Journal of Fisheries and Aquatic Science, Vol 11(3), pp.206-215, 2016.
[62] A.D. Talpur, M.H.D. Ikahwanuddin, A.M.A. Bolong. Nutritional effect of ginger (Zingiber officinale) on immune response of Asian sea bass, Lates calcarifer (Bloch) and disease resistance against Vibrio harveyi. Aquaculture, Vol 400-401, pp. 46-52, 2013.

[63] A.H.Houston. Blood and Circulation. In: Schreck, C.B. and Moyle, P.B.(Eds)., Methods in Fish Biology. American Fisheries Society, Bethesda, Maryland, 1990, pp. 273-334.

[64] N. Pedro, A.I. Guijarro, M.A. Lopez-patino, M.J. Martinez-Alvarez, R. Delgado. Daily and seasonal variation in hematological and blood biochemical parameters in the tench, inca tinca Linnaeus, 1758. Aquaculture Research, Vol 36, pp.1185-1196, 2005.

[65] F.M. Fazlolahzadeh, K. Keramati, S. Nazifi, S. Shirian, S. Seifi. Effect of garlic (Allium sativum) on hematological parameters and plasma activities of ALT and AST of Rainbow trout in temperature stress. Australian Journal of Basic Application Science, Vol 5(9), pp. 8490, 2011. 